Full length article

\title{
Dietary camu camu, Myrciaria dubia, enhances immunological response in Nile tilapia
}

\author{
Jefferson Yunis-Aguinaga ${ }^{\mathrm{a}}$, Dayanne C. Fernandes ${ }^{\mathrm{b}}$, Silas F. Eto ${ }^{\mathrm{b}}$, Gustavo S. Claudiano ${ }^{\mathrm{b}}$, \\ Paulo F. Marcusso ${ }^{b}$, Fausto A. Marinho-Neto ${ }^{b}$, João B.K. Fernandes ${ }^{a}$, \\ Flávio R. de Moraes ${ }^{a, b}$, Julieta R. Engrácia de Moraes ${ }^{\text {a, b, * }}$ \\ a Aquaculture Center of Unesp, Sao Paulo, Brazil \\ ${ }^{\mathrm{b}}$ Department of Veterinary Pathology, School of Agrarian and Veterinary Sciences, Sao Paulo State University (Unesp), Via Prof. Paulo Donato Castellane, km \\ 05, Jaboticabal, Sao Paulo, Brazil
}

\section{A R T I C L E I N F O}

\section{Article history:}

Received 9 June 2016

Received in revised form

6 August 2016

Accepted 13 August 2016

Available online 15 August 2016

\section{Keywords:}

Amazon herb

Phytotherapy

Hematology

Direct agglutination

Serum bactericidal activity

\begin{abstract}
A B S T R A C T
Camu camu, Myrciaria dubia, is an Amazon plant that presents high levels of vitamin C in its composition. Several studies in animals and humans have demonstrated their efficiency in the prevention and treatment of various diseases. However, there are no reports of its properties in fish. The aim of this study was to evaluate the effect of the oral administration of the extract of this plant in the immune parameters in Nile tilapia, Oreochromis niloticus. 400 Nile tilapia $(80 \pm 5 \mathrm{~g})$ were randomly distributed into 20 tanks with $1500 \mathrm{~L}$ capacity each (20 fish/tank). After a week of adaptation to environmental conditions, it was provided a diet for 5 weeks, using different levels of inclusion of camu camu extract: $0,50,100,250$, and $500 \mathrm{mg} / \mathrm{kg}$ of feed. Each treatment consisted of four replicates. It was obtained $40.5 \mathrm{mg}$ of vitamin C/g of camu camu pulp powder by high-performance liquid chromatography. At the end of the trial period, fish were inoculated with Aeromonas hydrophila in the swim bladder. Samples were taken after 6; 24 and $48 \mathrm{~h}$ of the challenge. Results revealed that fish supplemented with this herb showed significant increase $(\mathrm{P}<0.05)$ in white blood cells counts in blood and exudate, burst respiratory activity, lysozyme activity, serum bactericidal activity, direct agglutination, and melanomacrophage centers count. Red blood cells count, hemoglobin, hematocrit, and biochemical profile of fish supplemented with the herb presented no statistical differences compared to control group $(\mathrm{P}>0.05)$. No histopathological lesions were observed in intestine, kidney, spleen, and gills. It can be concluded that the addition of Myrciaria dubia in tilapia feed improves the immune response and the growth after 5 weeks, especially, at a dose of $500 \mathrm{mg} / \mathrm{kg}$.
\end{abstract}

(C) 2016 Published by Elsevier Ltd.

\section{Introduction}

Camu camu, Myrciaria dubia, is an Amazon plant that belongs to the group of "super fruits" due to mainly its high levels of vitamin C in its composition. Furthermore, this plant presents carotenoids, flavonoids, and anthocyanins that have antioxidant properties [1]. It is commonly used in the preparation of juices, concentrates, and for the production of vitamin C pills [2] in the Peruvian Amazon.

The antioxidant capacity of this fruit was demonstrated in in vivo experiments using raw extract of this fruit in diabetic rats increasing the plasma antioxidant activity and reducing triacylglycerol, and lipid peroxidation [3]. In in vitro experiments,

\footnotetext{
* Corresponding author. Aquaculture Center of Unesp, Sao Paulo, Brazil. E-mail address: julietaengracia@gmail.com (J.R.E. de Moraes).
}

camu camu juice produced a dose-dependent scavenger activity in relation to DPPH free radical on mice blood cells [4]. In humans, dietary camu camu produced decrease of oxidative stress and inflammatory markers such as levels of urinary 8-hydroxy-deoxyguanosine, total reactive oxygen species, high sensitivity $C$ reactive protein, IL-6, and IL-8 [5].

Most of camu camu properties are attributed to the high content of vitamin $C$ in the fruit. The effects of this vitamin in Nile tilapia were widely studied by Ibrahem et al. [6], Lim et al. [7], Ozkan et al. [8], and Barros et al. [9]. In fish, it was found that it is essential for controlling stress, protecting cell membranes, and exerts an immunomodulatory effect $[6,10,11]$.

However, there are no reports of camu camu supplementation in fish. In this study, we evaluated the effect of the oral administration of the extract of this plant on the immune and physiological 
parameters in Nile tilapia, Oreochromis niloticus.

\section{Material and methods}

\subsection{Fish and management}

Nile tilapias $(80.2 \pm 5 \mathrm{~g})$ were placed in two tanks $(1500 \mathrm{~L})$ to acclimation to laboratorial condition for two weeks. In this period, fish were fed twice a day with a commercial feed for the species ( $3 \%$ of the biomass).

\subsection{Myrciaria dubia}

A commercial extract of $M$. dubia from Peru was used in this study (Bionaturista, S.A. of Peru; cod. 100242) and directly shipped to our laboratory. The extract was powdered and stored in plastic bags at $4{ }^{\circ} \mathrm{C}$. To prepare a stock solution (10\%), the extract was suspended in deionized water and used in the biological test.

Vitamin C (ascorbic acid) concentrations were quantified by high-performance liquid chromatography (HPLC) according to Campos et al. [12] modified by Neves et al. [1]. It was obtained $40.5 \mathrm{mg} / \mathrm{g}$ of camu camu pulp powder.

\subsection{Diet preparation}

The experimental diets were prepared with local ingredients containing 0 (control group); 50; 100; 250; and $500 \mathrm{mg}$ of camu camu $\mathrm{Kg}^{-1}$ of feed. The basal diet [13] were mixed mechanically and extruded through a $1 \mathrm{~mm}$ die. After extrusion, the extract of camu camu was incorporated by spraying. The resulting pellets were stored at $-4{ }^{\circ} \mathrm{C}$ until use.

\subsection{Experimental design}

Nile tilapia were randomly distributed into 20 tanks with $1500 \mathrm{~L}$ capacity each (20 fish/tank). Each treatment consisted of four replicates. Diet was provided for 5 weeks. The experimental trial for effects of camu camu on physio-immunological parameters in Nile tilapia were conducted by feeding with the diets described above. The levels of camu camu used were determined by preliminary tests on this species. In the experimental period, water quality remained in the range of fish comfort (DO: $6.9 \pm 0.6 \mathrm{mg} \mathrm{L}^{-1}$; $\mathrm{T}^{\circ}$ : $24.9 \pm 1.4^{\circ} \mathrm{C} ; \mathrm{pH}: 7.2 \pm 0.7$; and conductivity: $\left.142.5 \pm 16.9 \mathrm{~S} \mathrm{~cm}^{-1}\right)$. It was used a multi-parameter probe (YSI Model MPS 556, Chicago, US). Tanks water was supplied with spring water with flow rate of $10 \mathrm{~L} \mathrm{~min}^{-1}$. Fish were fed three times a day with feed mentioned above.

\subsection{Bacteria and lethal dose 50}

Aeromonas hydrophila were isolated from naturally infected Nile tilapia that presented typical clinical signs of the disease [14]. Bacterium was identified using the biochemical tests for oxidase positive Gram negative bacteria (Bactray III, Laborclin ${ }^{\circledR}$, Pinhais, Brazil). The genetic characterization of the bacteria was performed using the Wizard Genomic DNA Purification Kit (Promega, Madison, UE) according to the methodology of the manufacturer. 16S ribosomal RNA gene amplification was performed according to Sarkar et al. [15]. The sequences were analyzed using the BLAST algorithm at the National Center for Biotechnology Information database (http://www.ncbi.nlm.nih.gov/blast/) for similarity to known genes confirming the bacterium species. The determination of the lethal dose 50 (LD50) followed the recommendations of Castro et al. [14] and was determined in a $3 \times 10^{9} \mathrm{CFU} \mathrm{mL}^{-1}$.

\subsection{Hematology and serum glucose levels}

After 6, 24, and $48 \mathrm{~h}$ post-stimulus (HPS), the fish were anesthetized with benzocaine solution (Sigma-Aldrich Laboratory, Steinheim, Germany) $(1: 20,000)$ diluted in $98 \%$ alcohol $\left(0.1 \mathrm{~g} \mathrm{~mL}^{-1}\right)$ and blood samples were collected from the caudal vein into heparinized tubes (10\%) and stained with May-Grünwal-GiemsaWright method to carry out white blood cells and thrombocytes counts [16]. RBC and blood measurement indices were performed according to Silva et al. [17]. Blood glucose was measured immediately after the fish captured using One Touch Ultra Mini ${ }^{\text {тм }}$ (Johnson \& Johnson Medical, Brazil).

\subsection{Biochemical profile}

The methodology used in this assay was described previously by Brito et al. [18] using an automatic multichannel analyzer ChemWell (Awareness Technology Inc.) following the manufacturer's instructions and using commercial kits of Labtest Diagnostica (Minas Gerais, Brazil). Total protein concentration was determined by using the biuret method, albumin by using bromocresol green method, urea by UV enzymatic kinetic method, creatinine by alkaline picrate method, calcium by O-resolphthalein-CPC method, and phosphorus by phosphomolybdate method.

\subsection{Induction and evaluation of acute aerocystitis}

The methodology used in this assay was described previously by Yunis-Aguinaga et al. [13]. The swim bladder was the organ chooses to inoculate the bacteria and collect the exudate due to its properties [19]. Total and differential counts of the cells accumulated at the swim bladder were performed according to Martins et al. [20].

\subsection{Leukocyte respiratory burst and serum lysozyme}

Using blood sampled from the caudal vein at the different evaluation times, the leukocyte respiratory burst by turbidometric assay using nitroblue tetrazolium (NBT) according to Castro et al. [14] and serum lysozyme concentration through turbidimetric assay [13] were determined.

\subsection{Serum bactericidal activity}

The bactericidal capacity of serum was measured according the methodology of Rao et al. [21]. Briefly, Aeromonas hydrophila was centrifuged, washed, and suspended in PBS. Then, the bacterial suspension was serially diluted (1:10) with PBS, incubating $50 \mu \mathrm{l}$ of the diluted bacterial suspension with $200 \mu \mathrm{l}$ of the serum for $1 \mathrm{~h}$ at $37^{\circ} \mathrm{C}$. PBS replaced the serum in the control group. The number of viable bacteria was determined by counting the colonies after culturing on TSA for $24 \mathrm{~h}$ at $27^{\circ} \mathrm{C}$.

\subsection{Direct agglutination}

Using serum and plasma, the antibody concentration was determined by erythrocytes agglutination according to Fernandes et al. [22]. The results were expressed as $\log _{2}$ of the reciprocals of the serum titers.

\subsection{Histopathology and melanomacrophage centers count}

Fragments of kidney, spleen, and liver were collected, fixed in Bouin solution for $3 \mathrm{~h}$ and transferred to $10 \%$ formol solution. These samples then underwent routine histological processing. Briefly, paraffin-block sections with a thickness $5 \mathrm{~mm}$ were cut and 
mounted on slides. These were stained with hematoxylin-eosin. Spleen samples were also stained with Toluidine blue stain to count melanomacrophage centers (MMCs). For this, five fields were randomly selected on each slide. Thus, 140 readings per treatment were performed at $400 \times$ magnification. After each field had been photographed, the area was measured $\left(\mathrm{mm}^{2}\right)$ and the number of MMCs per field counted $[13,23]$.

\subsection{Statistical analysis}

The results were subjected to analysis of variance and comparison of means through Tukey test at a significance level of $5 \%$.

\section{Results}

\subsection{Hematology and glucose levels}

Red blood cells count and blood measurement indices showed no differences between groups and sampling times $(\mathrm{P}>0.05$ ). Glucose levels decreased at 24 HPS (hours post-stimulus). However, at $48 \mathrm{HPS}$, fish supplemented with 250 and $500 \mathrm{mg} / \mathrm{kg}$ of camu camu in the feed recovered the initial values of glycemia (Table 1).

It was observed at 6 HPS that the group supplemented with the highest concentration of camu camu presented the highest concentration of white blood cells (WBC). 24 HPS, fish supplemented with 250 and $500 \mathrm{mg} / \mathrm{kg}$ of camu camu in the feed presented the highest concentration of WBC between groups and sampling times.

Finally, at last sampling time, fish supplemented with $250 / \mathrm{kg}$ of camu camu in the feed presented the highest WBC (Fig. 1A).

Neutrophils were more abundant at 24 and 48 HPS in blood, mainly in the groups supplemented with 250 and $500 \mathrm{mg} / \mathrm{kg}$ of camu camu in the feed. Thrombocytes showed no differences between groups and sampling times. Lymphocytes presented a similar concentration to that observed in neutrophils except that at 48 HPS, there were no differences between groups. Monocytes were the cell less abundant in this assay. In most cases, it was observed a progressive increase of these cells. It was also observed that fish supplemented with 250 and $500 \mathrm{mg} / \mathrm{kg}$ of camu camu in the feed presented the highest values at 24 and 48 HPS (Table 2).

\subsection{Biochemical profile}

There were observed no differences in total protein, albumin,
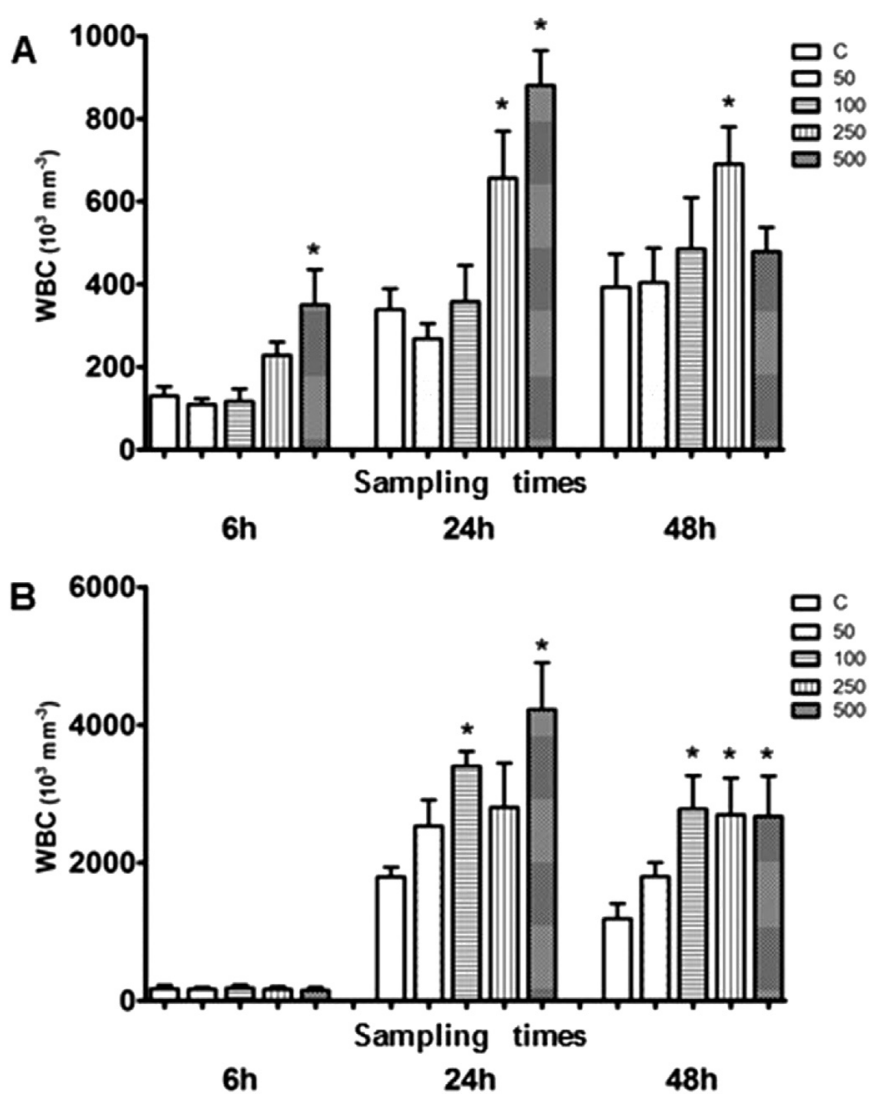

Fig. 1. White blood cells count (WBC) of blood (A) and WBC of swim bladder exudate (B) of 0 . niloticus fed 0 (non-supplement fish), 50, 100, 250, $500 \mathrm{mg}$ of Myrciaria dubia $\mathrm{kg}^{-1}$ of food after 5 weeks of supplementation. Values (means \pm SD) with an asterisk were significantly different comparing to the control group of the same sampling time $(\mathrm{P}<0.05)$.

creatinine, urea, calcium, and phosphorus serum levels in all sampling times $(\mathrm{P}>0.05)$ (Table 3$)$.

\subsection{Evaluation of acute aerocystitis}

At the first sampling time, it was observed no differences

\section{Table 1}

Hematology and serum glucose levels of $O$. niloticus after 5 weeks of supplementation with different concentrations of $M$. dubia at 6,24 , and 48 h after bacteria inoculation. Hct: hematocrit; Hb: hemoglobin; RBC: Red blood cell count; MCHC: mean corpuscular hemoglobin concentration; MCH: mean corpuscular hemoglobin; MCV: mean corpuscular volume; G: serum glucose.

\begin{tabular}{lllllllll}
\hline Hours & Groups & $\mathrm{Hct}(\%)$ & $\mathrm{Hb}\left(\mathrm{g} \mathrm{dL}^{-1}\right)$ & $\mathrm{RBC}\left(10^{4} \mu \mathrm{L}^{-1}\right)$ & $\mathrm{MCHC}\left(\mathrm{g} \mathrm{dL}^{-1}\right)$ & $\mathrm{MCH}(\mathrm{pg})$ & $\mathrm{MCV}(\mathrm{fL})$ & $\mathrm{G}(\mathrm{mg} \mathrm{dL}$ \\
\hline 6 & $\mathrm{C}$ & $34.40 \pm 4.34$ & $9.11 \pm 0.72$ & $138.80 \pm 60.45$ & $26.73 \pm 3.01$ & $81.83 \pm 47.93$ & $189.47 \pm 55.60$ & $97.34 \pm 5.18 \mathrm{Aa}$ \\
& 50 & $36.00 \pm 4.24$ & $9.58 \pm 1.10$ & $145.20 \pm 66.72$ & $26.19 \pm 3.88$ & $77.64 \pm 33.08$ & $252.56 \pm 23.45$ & $92.61 \pm 22.59 \mathrm{Aa}$ \\
& 100 & $38.60 \pm 6.99$ & $10.68 \pm 1.27$ & $165.50 \pm 61.78$ & $28.39 \pm 6.22$ & $75.49 \pm 32.43$ & $246.94 \pm 79.77$ & $96.67 \pm 8.88 \mathrm{Aa}$ \\
& 250 & $35.00 \pm 1.00$ & $10.86 \pm 0.43$ & $156.25 \pm 69.57$ & $31.39 \pm 2.42$ & $79.97 \pm 31.10$ & $223.25 \pm 97.55$ & $108.42 \pm 5.69 \mathrm{Aa}$ \\
& 500 & $33.25 \pm 2.63$ & $10.02 \pm 1.23$ & $172.60 \pm 52.80$ & $30.22 \pm 4.00$ & $58.16 \pm 18.96$ & $196.79 \pm 73.49$ & $101.89 \pm 9.37 \mathrm{Aa}$ \\
\hline 24 & $\mathrm{C}$ & $38.50 \pm 6.98$ & $9.05 \pm 2.07$ & $144.83 \pm 63.43$ & $24.10 \pm 8.23$ & $73.56 \pm 37.36$ & $276.38 \pm 78.53$ & $22.77 \pm 13.37 \mathrm{Bb}$ \\
& 50 & $37.50 \pm 3.87$ & $9.67 \pm 1.44$ & $167.80 \pm 80.66$ & $24.92 \pm 6.73$ & $66.91 \pm 29.59$ & $228.96 \pm 73.00$ & $43.58 \pm 12.25 \mathrm{ABb}$ \\
& 100 & $38.60 \pm 2.19$ & $9.04 \pm 2.32$ & $147.67 \pm 65.75$ & $22.55 \pm 6.19$ & $67.44 \pm 18.67$ & $285.58 \pm 98.34$ & $57.01 \pm 1.19 \mathrm{Ab}$ \\
& 250 & $36.88 \pm 3.04$ & $9.60 \pm 2.51$ & $172.83 \pm 75.34$ & $24.91 \pm 7.19$ & $53.30 \pm 12.66$ & $217.71 \pm 67.57$ & $55.01 \pm 7.96 \mathrm{Ab}$ \\
& 500 & $38.50 \pm 4.23$ & $10.30 \pm 0.79$ & $164.40 \pm 33.49$ & $26.47 \pm 2.91$ & $63.24 \pm 14.45$ & $248.21 \pm 58.78$ & $54.36 \pm 16.51 \mathrm{Ab}$ \\
\hline 48 & $\mathrm{C}$ & $37.83 \pm 6.77$ & $9.04 \pm 1.24$ & $161.83 \pm 73.02$ & $25.48 \pm 4.32$ & $56.28 \pm 28.43$ & $188.14 \pm 59.98$ & $45.15 \pm 14.46 \mathrm{Bb}$ \\
& 50 & $39.14 \pm 5.98$ & $9.87 \pm 1.60$ & $161.14 \pm 43.08$ & $25.80 \pm 7.39$ & $64.20 \pm 20.93$ & $237.33 \pm 56.70$ & $66.55 \pm 13.08 \mathrm{ABb}$ \\
& 100 & $39.00 \pm 2.45$ & $10.69 \pm 1.13$ & $169.17 \pm 67.89$ & $27.42 \pm 2.38$ & $68.01 \pm 30.45$ & $215.23 \pm 74.14$ & $66.58 \pm 14.04 \mathrm{ABb}$ \\
& 250 & $36.50 \pm 3.54$ & $9.56 \pm 0.48$ & $183.80 \pm 61.33$ & $25.67 \pm 1.75$ & $58.10 \pm 23.03$ & $162.57 \pm 28.61$ & $81.40 \pm 10.54 \mathrm{Aab}$ \\
& 500 & $37.50 \pm 8.73$ & $9.21 \pm 1.37$ & $167.17 \pm 28.15$ & $25.17 \pm 9.49$ & $54.50 \pm 10.99$ & $212.27 \pm 64.49$ & $79.84 \pm 8.80 \mathrm{Aab}$ \\
\hline
\end{tabular}

Values (means \pm SD) with different capital letters compare treatments in the column within each period. Lowercase letters compare sampling times in the column (6, 24, and $48 \mathrm{~h})(\mathrm{P}<0.05)$. 
Table 2

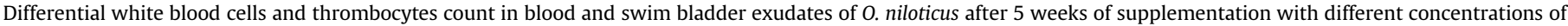
M. dubia at 6,24 , and $48 \mathrm{~h}$ after bacteria inoculation.

\begin{tabular}{|c|c|c|c|c|c|}
\hline Time(hours) & Treatment & Neutrophils $\left(10^{3} \mu \mathrm{L}^{-1}\right)$ & Thrombocytes $\left(10^{3} \mu \mathrm{L}^{-1}\right)$ & Lymphocytes $\left(10^{3} \mu \mathrm{L}^{-1}\right)$ & Monocytes $\left(10^{3} \mu \mathrm{L}^{-1}\right)$ \\
\hline \multicolumn{6}{|c|}{ Differential leukocytes count in blood } \\
\hline \multirow[t]{5}{*}{6} & Control & $37.54 \pm 5.76 \mathrm{Aa}$ & $42.62 \pm 8.73 \mathrm{Aa}$ & $48.41 \pm 10.01 \mathrm{Aa}$ & $1.42 \pm 0.43 \mathrm{Aa}$ \\
\hline & T 50 & $28.93 \pm 3.63 \mathrm{Aa}$ & $43.67 \pm 8.15 \mathrm{Aa}$ & $34.68 \pm 3.42 \mathrm{Aa}$ & $2.32 \pm 0.78 \mathrm{Aa}$ \\
\hline & Т 100 & $29.94 \pm 7.87 \mathrm{Ab}$ & $35.21 \pm 7.78 \mathrm{Aa}$ & $49.45 \pm 15.96 \mathrm{Aa}$ & $2.40 \pm 0.58 \mathrm{Ab}$ \\
\hline & Т 250 & $63.63 \pm 13.89 \mathrm{Ab}$ & $78.51 \pm 11.99 \mathrm{Aa}$ & $83.00 \pm 7.13 \mathrm{Ab}$ & $3.67 \pm 1.16 \mathrm{Ab}$ \\
\hline & T 500 & $107.43 \pm 25.62 \mathrm{Ac}$ & $115.17 \pm 32.28 \mathrm{Aa}$ & $120.73 \pm 29.89 \mathrm{Ab}$ & $6.47 \pm 1.70 \mathrm{Ab}$ \\
\hline \multirow[t]{5}{*}{24} & Control & $99.86 \pm 22.04 \mathrm{Ca}$ & $77.80 \pm 7.91 \mathrm{Aa}$ & $152.40 \pm 22.06 \mathrm{CDa}$ & $8.34 \pm 3.04 \mathrm{Ba}$ \\
\hline & T 50 & $88.15 \pm 13.76 C a$ & $64.05 \pm 11.05 \mathrm{Aa}$ & $106.39 \pm 14.19 \mathrm{Da}$ & $10.02 \pm 1.85 \mathrm{Ba}$ \\
\hline & Т 100 & $128.71 \pm 28.03 \mathrm{BCab}$ & $89.16 \pm 19.54 \mathrm{Aa}$ & $129.16 \pm 39.13 \mathrm{Da}$ & $11.17 \pm 3.45 \mathrm{Bab}$ \\
\hline & Т 250 & $265.53 \pm 42.35 \mathrm{ABa}$ & $94.76 \pm 15.87 \mathrm{Aa}$ & $276.09 \pm 54.23 \mathrm{BCa}$ & $20.42 \pm 4.74 \mathrm{ABb}$ \\
\hline & T 500 & $399.66 \pm 51.58 \mathrm{Aa}$ & $150.58 \pm 15.39 \mathrm{Aa}$ & $296.96 \pm 31.08 \mathrm{ABa}$ & $33.61 \pm 3.88 \mathrm{Aa}$ \\
\hline \multirow[t]{5}{*}{48} & Control & $111.24 \pm 23.70 \mathrm{Ba}$ & $103.10 \pm 29.04 \mathrm{Aa}$ & $167.34 \pm 30.61 \mathrm{Aa}$ & $11.52 \pm 2.91 \mathrm{Ca}$ \\
\hline & T 50 & $140.17 \pm 28.99 B a$ & $107.22 \pm 31.27 \mathrm{Aa}$ & $144.13 \pm 23.67 \mathrm{Aa}$ & $12.48 \pm 4.10 \mathrm{Ca}$ \\
\hline & Т 100 & $193.48 \pm 53.42 \mathrm{ABa}$ & $142.70 \pm 38.43 \mathrm{Aa}$ & $125.20 \pm 26.04 \mathrm{Aa}$ & $24.42 \pm 9.16 \mathrm{BCa}$ \\
\hline & Т 250 & $308.95 \pm 40.19 A a$ & $162.56 \pm 28.65 \mathrm{Aa}$ & $176.97 \pm 27.27 \mathrm{Aab}$ & $42.52 \pm 8.09 \mathrm{ABa}$ \\
\hline & T 500 & $238.08 \pm 27.51 \mathrm{ABb}$ & $91.28 \pm 19.26 A a$ & $112.69 \pm 16.95 \mathrm{Ab}$ & $36.55 \pm 5.74 \mathrm{ABa}$ \\
\hline \multicolumn{6}{|c|}{ Differential leukocytes count in swim bladder exudate } \\
\hline \multirow[t]{5}{*}{6} & Control & $52.90 \pm 13.46 \mathrm{Aa}$ & $56.29 \pm 13.86 \mathrm{Aa}$ & $64.81 \pm 18.27 \mathrm{Ab}$ & $0.00 \pm 0.00 \mathrm{Aa}$ \\
\hline & T 50 & $53.91 \pm 11.38 \mathrm{Aa}$ & $63.74 \pm 13.76 \mathrm{Ab}$ & $47.15 \pm 6.35 \mathrm{Ab}$ & $1.00 \pm 0.47 \mathrm{Aa}$ \\
\hline & Т 100 & $54.20 \pm 11.95 \mathrm{Ab}$ & $61.94 \pm 15.14 \mathrm{Ab}$ & $67.88 \pm 14.23 \mathrm{Ab}$ & $1.98 \pm 0.60 \mathrm{Aa}$ \\
\hline & Т 250 & $48.85 \pm 12.95 \mathrm{Ab}$ & $54.46 \pm 13.87 \mathrm{Ab}$ & $61.67 \pm 14.52 \mathrm{Ab}$ & $0.62 \pm 0.46 \mathrm{Aa}$ \\
\hline & T 500 & $46.55 \pm 9.60 A c$ & $47.11 \pm 9.44 \mathrm{Ab}$ & $55.53 \pm 21.27 \mathrm{Ab}$ & $2.41 \pm 1.17 \mathrm{Ab}$ \\
\hline \multirow[t]{5}{*}{24} & Control & $515.16 \pm 86.15 \mathrm{Ba}$ & $538.18 \pm 52.39 \mathrm{Ba}$ & $712.89 \pm 42.67 \mathrm{Aa}$ & $28.84 \pm 8.24 \mathrm{Ba}$ \\
\hline & T 50 & $829.22 \pm 183.64 \mathrm{Ba}$ & $743.59 \pm 118.68 \mathrm{ABa}$ & $904.37 \pm 115.21 \mathrm{Aa}$ & $58.42 \pm 10.24 \mathrm{ABa}$ \\
\hline & Т 100 & $1237.91 \pm 139.95 \mathrm{ABa}$ & $993.04 \pm 91.62 \mathrm{ABa}$ & $1114.51 \pm 140.43 \mathrm{Aa}$ & $57.73 \pm 18.63 \mathrm{ABa}$ \\
\hline & Т 250 & $1141.56 \pm 290.03 \mathrm{Ba}$ & $734.93 \pm 158.66 \mathrm{ABa}$ & $882.88 \pm 211.41 \mathrm{Aa}$ & $47.83 \pm 16.58 \mathrm{ABa}$ \\
\hline & T 500 & $2019.13 \pm 371.94 A a$ & $1087.64 \pm 155.94 A a$ & $1000.26 \pm 163.83 A a$ & $119.17 \pm 29.12 \mathrm{Aa}$ \\
\hline \multirow[t]{5}{*}{48} & Control & $350.21 \pm 106.28 \mathrm{Aa}$ & $378.29 \pm 67.31 \mathrm{Aa}$ & $443.06 \pm 63.67 \mathrm{Aab}$ & $16.45 \pm 7.29 \mathrm{Ba}$ \\
\hline & Т 50 & $502.82 \pm 46.58 \mathrm{Aa}$ & $582.39 \pm 50.81 \mathrm{Aa}$ & $687.26 \pm 93.85 \mathrm{Aa}$ & $33.53 \pm 13.21 \mathrm{ABa}$ \\
\hline & Т 100 & $962.84 \pm 179.57 \mathrm{Aa}$ & $811.82 \pm 90.11 \mathrm{Aa}$ & $921.01 \pm 208.62 \mathrm{Aa}$ & $85.92 \pm 25.84 \mathrm{ABa}$ \\
\hline & Т 250 & $1001.3 \pm 79.88 \mathrm{Aa}$ & $605.40 \pm 54.62 \mathrm{Aa}$ & $995.65 \pm 140.17 \mathrm{Aa}$ & $84.49 \pm 30.90 \mathrm{ABa}$ \\
\hline & T 500 & $1128.7 \pm 275.20 \mathrm{Ab}$ & $729.42 \pm 169.43 \mathrm{Aa}$ & $705.52 \pm 170.91 \mathrm{Aa}$ & $109.54 \pm 23.86 \mathrm{Aa}$ \\
\hline
\end{tabular}

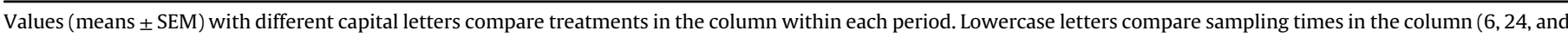
48 h) $(\mathrm{P}<0.05)$.

Table 3

Biochemical profile of 0 . niloticus after 5 weeks of supplementation with different concentrations of M. dubia at 6, 24, and 48 h after bacteria inoculation.

\begin{tabular}{|c|c|c|c|c|c|c|c|}
\hline Hours & Groups & Total protein & Albumin & Creatinine & Urea & Calcium & Phosphorus \\
\hline \multirow[t]{5}{*}{6} & $\mathrm{C}$ & $3.3 \pm 0.39$ & $0.82 \pm 0.07$ & $0.72 \pm 0.18$ & $4.00 \pm 0.71$ & $12.95 \pm 1.21$ & $5.72 \pm 1.28$ \\
\hline & 50 & $3.36 \pm 0.36$ & $0.86 \pm 0.12$ & $0.45 \pm 0.10$ & $3.20 \pm 1.64$ & $13.40 \pm 1.41$ & $5.80 \pm 1.44$ \\
\hline & 100 & $3.66 \pm 0.22$ & $0.92 \pm 0.11$ & $0.65 \pm 0.19$ & $3.75 \pm 0.50$ & $13.28 \pm 0.76$ & $5.86 \pm 1.93$ \\
\hline & 250 & $3.74 \pm 0.61$ & $0.99 \pm 0.26$ & $0.68 \pm 0.22$ & $3.40 \pm 1.14$ & $13.46 \pm 0.58$ & $6.26 \pm 0.90$ \\
\hline & 500 & $3.36 \pm 0.52$ & $0.88 \pm 0.27$ & $0.68 \pm 0.18$ & $3.33 \pm 0.58$ & $12.84 \pm 0.49$ & $6.36 \pm 1.31$ \\
\hline \multirow[t]{5}{*}{24} & $\mathrm{C}$ & $3.68 \pm 0.38$ & $0.88 \pm 0.12$ & $0.56 \pm 0.33$ & $3.40 \pm 0.89$ & $14.32 \pm 1.02$ & $6.76 \pm 1.49$ \\
\hline & 50 & $3.85 \pm 0.21$ & $0.93 \pm 0.05$ & $0.28 \pm 0.11$ & $3.00 \pm 1.00$ & $13.72 \pm 0.46$ & $6.08 \pm 1.06$ \\
\hline & 100 & $3.63 \pm 0.10$ & $0.80 \pm 0.04$ & $0.30 \pm 0.12$ & $3.20 \pm 2.68$ & $14.20 \pm 1.14$ & $6.72 \pm 1.34$ \\
\hline & 250 & $3.88 \pm 0.31$ & $0.89 \pm 0.09$ & $0.34 \pm 0.09$ & $2.40 \pm 0.55$ & $13.74 \pm 0.70$ & $6.60 \pm 1.58$ \\
\hline & 500 & $3.68 \pm 0.34$ & $0.87 \pm 0.13$ & $0.42 \pm 0.08$ & $2.00 \pm 0.71$ & $13.38 \pm 1.00$ & $6.08 \pm 2.10$ \\
\hline \multirow[t]{5}{*}{48} & $\mathrm{C}$ & $4.13 \pm 0.33$ & $1.00 \pm 0.13$ & $0.60 \pm 0.14$ & $3.20 \pm 1.30$ & $13.44 \pm 1.14$ & $6.40 \pm 1.30$ \\
\hline & 50 & $3.75 \pm 0.10$ & $0.80 \pm 0.29$ & $0.42 \pm 0.11$ & $3.00 \pm 1.73$ & $13.32 \pm 1.36$ & $5.48 \pm 1.20$ \\
\hline & 100 & $3.83 \pm 0.30$ & $0.96 \pm 0.13$ & $0.35 \pm 0.19$ & $3.80 \pm 0.4$ & $13.06 \pm 0.90$ & $5.78 \pm 2.07$ \\
\hline & 250 & $3.53 \pm 0.32$ & $1.07 \pm 0.20$ & $0.52 \pm 0.11$ & $3.40 \pm 1.67$ & $13.26 \pm 0.66$ & $6.42 \pm 0.74$ \\
\hline & 500 & $3.55 \pm 0.06$ & $0.90 \pm 0.05$ & $0.50 \pm 0.17$ & $3.50 \pm 1.52$ & $13.24 \pm 0.61$ & $6.02 \pm 1.14$ \\
\hline
\end{tabular}

between groups. However, after 24 HPS, there were observed a large increased in all groups. Fish supplemented with 100 and $500 \mathrm{mg} / \mathrm{kg}$ of camu camu in the feed presented the highest values at this sampling time. Finally, 48 HPS, there were observed that fish supplemented with 100,250 , and $500 \mathrm{mg} / \mathrm{kg}$ of camu camu in the feed presented higher WBC comparing to control group (Fig. 1B).

It was observed increased numbers of neutrophils at the site of inflammation in the groups supplemented with $500 \mathrm{mg} / \mathrm{kg}$. The highest levels were detected at 24 h. At 6 HPS, it was observed less number of thrombocytes comparing with the other sampling times except for control group which it remains constant in all sampling times. At $24 \mathrm{HPS}$, the groups supplemented with $500 \mathrm{mg} / \mathrm{kg}$ presented more thrombocytes than control group. At 24 and 48 HPS, fish presented more lymphocytes than the first sampling time and the group supplemented with $500 \mathrm{mg} / \mathrm{kg}$ presented more monocytes than control group (Table 2). 


\subsection{Leukocyte respiratory burst}

The results showed that Myrciaria dubia extract enhanced the burst respiratory activity in all sampling times $(P<0.05)$. In the first two sampling times, 100,250 and $500 \mathrm{mg}$ of $M$. dubia $\mathrm{kg}^{-1}$ of feed presented higher response $(\mathrm{P}<0.05)$. At $48 \mathrm{HPS}$, the group $250 \mathrm{mg}$ of $M$. dubia $\mathrm{kg}^{-1}$ of feed showed the higher response comparing with control group $(P<0.05)$. In all sampling times the group supplemented with $50 \mathrm{mg}$ of $M$. dubia $\mathrm{kg}^{-1}$ of feed showed similar response with control group $(\mathrm{P}>0.05)$ (Fig. 2).

\subsection{Serum lysozyme}

The level of activity of lysozyme at 6 HPS showed similar responses in all groups $(\mathrm{P}>0.05)$. All supplemented groups with $M$. dubia presented higher response comparing with control group at 24 and 48 HPS $(P<0.05)$ (Fig. 3).

\subsection{Serum bactericidal activity}

Control group at 6 and 24 HPS and fish supplemented with $50 \mathrm{mg}$ of M. dubia $\mathrm{kg}^{-1}$ of feed at 6 HPS presented similar response that the group total bacteria (without any serum) $(P>0.05)$. All other groups presented less number of bacterial colonies comparing with the group total bacteria (without any serum) $(\mathrm{P}<0.05)$ (Fig. 5).

\subsection{Direct agglutination}

The groups supplemented with 50,100, and $250 \mathrm{mg}$ of $M$. dubia $\mathrm{kg}^{-1}$ of feed presented similar response to control group $(\mathrm{P}>0.05)$. The group supplemented with $500 \mathrm{mg}$ of $M$. dubia $\mathrm{kg}^{-1}$ of feed showed higher serum titer than control group $(P<0.05)$ (Fig. 4).

\subsection{Histopathology}

No histopathological lesions related to the supplementation were observed in intestine, kidney, spleen, and gills in all sampling times (data no showed).

\subsection{Melanomacrophage centers count}

The MMCs in the spleen presented no differences at 6HPS

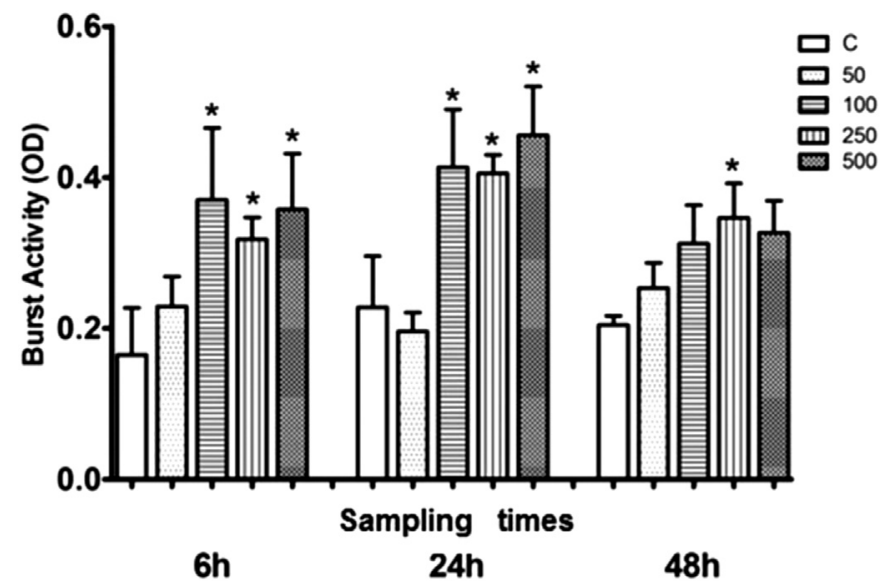

Fig. 2. Burst respiratory activity of 0 . niloticus fed 0 (non-supplement fish), 50, 100, $250,500 \mathrm{mg}$ of Myrciaria dubia $\mathrm{kg}^{-1}$ of food after 5 weeks of supplementation. Values (means $\pm \mathrm{SD}$ ) with an asterisk were significantly different comparing to the control group of the same sampling time $(\mathrm{P}<0.05)$.

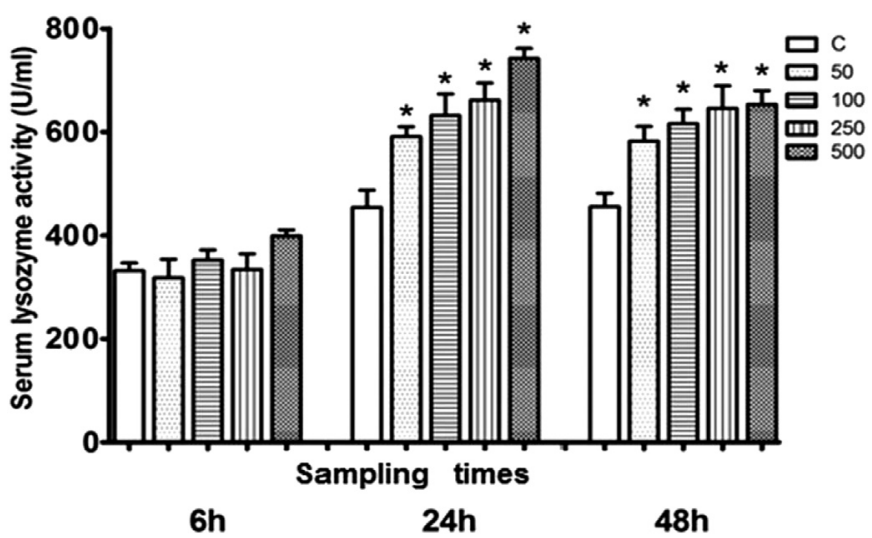

Fig. 3. Serum lysozyme activity of 0 . niloticus fed 0 (non-supplement fish), 50, 100 , 250, $500 \mathrm{mg}$ of Myrciaria dubia $\mathrm{kg}^{-1}$ of food after 5 weeks of supplementation. Values (means $\pm \mathrm{SD}$ ) with an asterisk were significantly different comparing to the control group of the same sampling time $(\mathrm{P}<0.05)$.

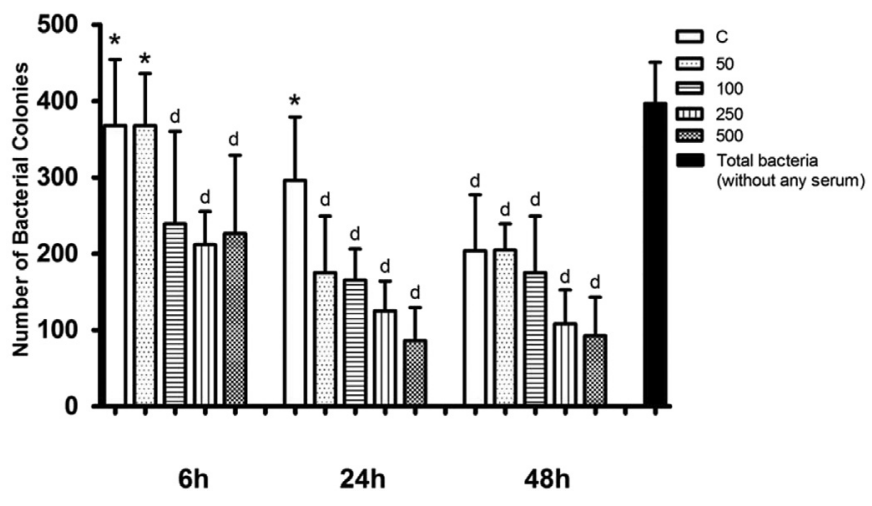

Fig. 4. Direct agglutination of $O$. niloticus fed 0 (non-supplement fish), 50, 100, 250, $500 \mathrm{mg}$ of Myrciaria dubia $\mathrm{kg}^{-1}$ of food after 5 weeks of supplementation. Values (means $\pm \mathrm{SD}$ ) with an asterisk were significantly different comparing to the control group of the same sampling time $(\mathrm{P}<0.05)$.

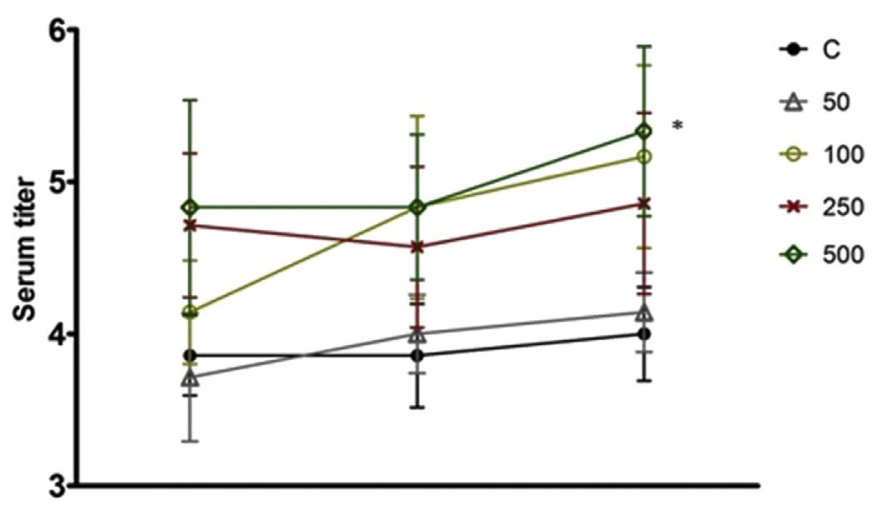

Sampling times

6h

24h

$48 h$

Fig. 5. Serum bactericidal activity of $O$. niloticus fed 0 (non-supplement fish), 50, 100, $250,500 \mathrm{mg}$ of Myrciaria dubia $\mathrm{kg}^{-1}$ of food after 5 weeks of supplementation. Values (means \pm SD) with an asterisk were significantly different within sampling time $(\mathrm{P}<0.05)$. Values (means $\pm \mathrm{SD}$ ) with a symbol "d" were significantly different to the group total bacteria (without any serum) $(\mathrm{P}<0.05)$. 
( $P>0.05)$. At 24 and 48 HPS, MMCs were larger in the groups supplemented with 100,250 , and $500 \mathrm{mg}$ of $M$. dubia $\mathrm{kg}^{-1}$ of feed $(\mathrm{P}<0.05)$. In all threated groups, MMCs after 48 HPS presented larger MMCs than 6 HPS $(\mathrm{P}<0.05)$ (Table 4$)$

\section{Discussion}

In recent years there has been increasing interest in natural products for boosting the defense mechanisms, increase natural resistance to infections, improve the antioxidant response, and facilitate the prevention and treatment of diseases [24]. The Amazon region has the highest number of species of medicinal plants in the world [25]. Recently, some of these herbs have been used for this purpose in fish: Uncaria tomentosa [13], Myrciaria sylvatica [26], and Lippia spp [27]. The present study demonstrated that diets supplemented with Myrciaria dubia enhanced the fish immunological response against bacteria.

The amount of ascorbic acid found in the samples it is according with the reports of Fracassetti et al. [28]. They found between 3.51 and $9.04 \mathrm{~g}$ of vitamin $\mathrm{C} / 100 \mathrm{~g}$ of the plant extract depending on the type of processing conditions.

The RBC, hematocrit, hemoglobin, and blood measurement indices showed no effect of the treatments, similar to the results of Chen et al. [29] in golden shiner and Ibrahem et al. [6] in Nile tilapia supplemented with vitamin C. There were no found reports of hematological parameters in mammals supplemented with camu camu.

In most cases, it was observed that serum glucose decreased in all sampling times at 24 and 48 HPS compared to 6 HPS likely due to the mobilization of energy for osmoregulatory purposes, mainly for the immunological system that has to counteract the bacterial infection. It was also observed that supplemented fish with the highest amount of camu camu presented more serum glucose than control group at 24 and 48 HPS, similar to the found by Zhou et al. [30] in Cobia fish supplemented with vitamin C. This suggests that dietary camu camu did influence fish homeostatic state. The main compound of camu camu, vitamin $\mathrm{C}$, is a potent antioxidant that prolongs the life of erythrocytes and plays an essential role in cellular respiration [31].

Several authors have found a direct relation between vitamin C supplementation and the quantity of white blood cells in tropical fish [32-34]. In the current study, we found similar results in all sampling times. The mechanism by which the high dose of vitamin $C$ influences increase in WBC is unclear, which require further investigation [35]. However, it is possible that it is related to the improvement of endothelial and liver function and its potent antioxidant capacity [36].

In the first sampling time, it was no observed differences of the WBC in the exudate of the swim bladder probably due to the short time between the stimulation and the sampling. However, in most cases, the groups that were supplemented with the highest amount of camu camu presented more quantity of WBC, similar to the found in blood WBC at 24 and 48 HPS. Which is important due to a rapidly chemotaxis and diapedesis of leukocytes from blood to the inflammatory focus is the key for an effective response to injury $[19,37,38]$.

Neutrophils are one of the first WBC that migrate to the infection site, where they recognize, ingest and destroy pathogens $[29,39]$. In this study, we found that neutrophils were more abundant at 24 and 48 HPS in blood and at the site of inflammation in the group supplemented with highest level of camu camu, which it is the first step for an efficient immunological response. Alike, the high number of lymphocytes observed, complemented the immune response due to these cells are involved in the specific immune response leading to the production of antibodies which may protect the species against pathogen invasion [38]. Affonso et al. [32] found similar response in Brycon amazonicus supplemented with vitamin C.

In fish, thrombocytes are involved in the release of eicosanoids, blood clotting, and general defense mechanisms [40,41] which likely complemented the immune response of the fish supplemented with $500 \mathrm{mg} / \mathrm{kg}$ of camu camu. Similar response was found by de Menezes et al. [33] in Arapaima gigas supplemented with high quantity of vitamin $C$ in the diet for 45 days.

Serum biochemistry results suggested that camu camu extract has no toxicological action in fish [18]. However, it is necessary further studies using higher concentration of the plant extract to affirm this statement [42].

Several tests are performed to assessing non-specific immune response: respiratory burst activity, serum lysozyme, serum bactericidal activity, melanomacrophage centers count, etc. $[13,14,20,22]$. The respiratory burst activity is used to evaluate the activity of leukocytes based in the production of superoxide anion that is toxic for pathogens. In the current study, it was observed a clear influence of the dietary supplementation with camu camu in this parameter, mainly in the groups supplemented with the major quantities of the plant. The increased activity of leukocytes implies that fish has a greater response against pathogens. Similar response was observed by Ibrahem et al. [6] in Nile tilapia supplemented with $500 \mathrm{mg}$ of vitamin C per kilogram for four weeks.

The ability of hydrolyze the peptidoglycans of the cell wall of pathogens by serum lysozyme makes it a natural antagonist to bacteria. In the present study, it was observed an increase in all supplemented fish at 24 and 48 HPS compared with control group, which added to the respiratory burst activity response, improve their response to pathogens. Dotta et al. [43] found no differences in this parameter in Nile tilapia supplemented Aloe barbadensis. These discrepant results may be due to the different herbs used and fish conditions.

The serum bactericidal activity is inversely correlated with fish health [44]. The largest number of bacterial colonies indicates that the serum did not prevent bacterial growth. El-Asely et al. [44] observed that the serum of Nile tilapia supplemented with honey bee pollen had better reactivity to bacterial growth than non-

Table 4

Area of melanomacrophage centers $\left(\mathrm{mm}^{2}\right)$ of $O$. niloticus after 5 weeks of supplementation with different concentrations of $M$. dubia at 6 , 24 , and $48 \mathrm{~h}$ after bacteria inoculation.

\begin{tabular}{lcc}
\hline Treatments & $6 \mathrm{~h}$ & $24 \mathrm{~h}$ \\
\hline Area of melanomacrophage center in the spleen $\left(\mu \mathrm{m}^{2}\right)$ & & \\
Control & $1217.21 \pm 93.91 \mathrm{Aa}$ & $1419.21 \pm 129.01 \mathrm{Ca}$ \\
T 50 & $1288.23 \pm 105.31 \mathrm{Ab}$ & $1403.77 \pm 150.44 \mathrm{Cb}$ \\
T 100 & $1539.49 \pm 115.02 \mathrm{Ab}$ & $2936.49 \pm 108.47 \mathrm{Ba}$ \\
T 250 & $1490.17 \pm 228.58 \mathrm{Ab}$ & $2815.05 \pm 201.41 \mathrm{Ba}$ \\
T 500 & $1592.21 \pm 101.79 \mathrm{Ab}$ & $4510.06 \pm 192.36 \mathrm{Aa}$ \\
\hline
\end{tabular}

Values (means \pm SD) with different capital letters compare treatments in the column within each period. Lowercase letters compare sampling times in the line (6, 24 , and $48 \mathrm{~h})(\mathrm{P}<0.05)$. 
supplemented fish. In our study, we found similar results in almost all groups. This suggest that supplementation with camu camu improved the antimicrobial capacity of the serum. Dotta et al. [43] found no differences of this activity in the same fish supplemented with Aloe barbadensis, likely due to the different conditions and plants used.

Humoral immune response is less studied in fish [22]. However, it is a very important and efficient pathway to control bacterial colonization. In this study, it was observed that Nile tilapia supplemented with $500 \mathrm{mg} / \mathrm{kg}$ of camu camu presented greater serum titer levels compared to control group, making it difficult for potential pathogens thrive in fish supplemented with the herb.

Histological findings complement the results of the biochemical profile. It was not observed lesions or histological changes in the supplemented groups compared to control group. Probably, the extract of this plant presents low toxicity in fish. In the Peruvian Amazon, this plant is widely consumed as juices and concentrates [2] without reports of toxicity [5].

Melanomacrophage centers (MMCs) are grouping of pigmented macrophages present in hematopoietic organs in fish, mainly in the spleen and kidneys [23]. The increase in the area and quantity of these MMCs is associated with an enhanced immune response due to these cells are involved in the destruction of foreign material, antigen processing, inflammatory process, and immune memory [13]. In this study, MMCs was significantly higher in supplemented fish comparing to non-supplement group at 24 and 48 HPS. It was also observed an enhancement in of the area of MMCs in all supplemented groups with camu camu in the time. This was not observed in the control group. These results agree with the findings by Yunis-Aguinaga et al. [13] in Nile tilapia, where the area of MMCs was proportional to the supplementation with cat's claw.

Supplementation of medicinal herbs in feed can improve fish health and thereby reduce management cost [45]. For the first time, the present study reports the effect of Myrciaria dubia on physiological and immune response in fish. The effects observed could be due the high content of vitamin $C$ in this herb. However, it is possible that others herb components also influenced the immunological response. For this, we consider necessary longer studies comparing the effects of this plant and pure vitamin $C$ to determine whether only this vitamin has an effect on fish or other of the herb constituents also influenced this response. Finally, we recommend dietary inclusion of $500 \mathrm{mg}$ of $M$ dubia. $\mathrm{kg}^{-1}$ for 5 weeks to improve Nile tilapia welfare.

\section{Acknowledgments}

The authors thank CAPES (Coordination for the Improvement of Higher Education Personnel) for a grant to Jefferson Yunis Aguinaga (PECPG-2013).

\section{References}

[1] L.C. Neves, V.X. da Silva, J.A. Pontis, A. Flach, S.R. Roberto, Bioactive compounds and antioxidant activity in pre-harvest camu-camu [Myrciaria dubia (HBK) Mc Vaugh] fruits, Sci. Hort. 186 (2015) 223-229.

[2] J. Azevedo, K. Borges, M. Genovese, R. Correia, D. Vattem, Neuroprotective effects of dried camu-camu (Myrciaria dubia HBK McVaugh) residue in C. elegans, Food Res. Int. 73 (2015) 135-141.

[3] A.S. Gonçalves, C. Lellis-Santos, R. Curi, M. Lajolo, M.I. Genovese, Frozen pulp extracts of camu-camu (Myrciaria dubia McVaugh) attenuate the hyperlipidemia and lipid peroxidation of Type 1 diabetic rats, Food Res. Int. 64 (2014) $1-8$.

[4] F. Da Silva, A. Arruda, A. Ledel, C. Dauth, N. Faria, R. Viana, A. de Barros, J. Nascimento, P. Pereira, Antigenotoxic effect of acute, subacute and chronic treatments with Amazonian camu-camu (Myrciaria dubia) juice on mice blood cells, Food Chem. Toxicol. 50 (2012) 2275-2281.

[5] T. Inoue, H. Komoda, T. Uchida, K. Node, Tropical fruit camu-camu (Myrciaria dubia) has anti-oxidative and anti-inflammatory properties, J. Cardiol. 52 (2008) 127-132.
[6] M. Ibrahem, M. Fathi, S. Mesalhy, A. El-Aty, Effect of dietary supplementation of inulin and vitamin $\mathrm{C}$ on the growth, hematology, innate immunity, and resistance of Nile tilapia (Oreochromis niloticus), Fish. Shellfish Immunol. 29 (2010) 241-246.

[7] C. Lim, M. Yildirim-Aksoy, T. Welker, P.H. Klesius, M.H. Li, Growth performance, immune response, and resistance to Streptococcus iniae of Nile Tilapia, Oreochromis niloticus, fed diets containing various levels of vitamins $\mathrm{C}$ and $\mathrm{E}$, J. World Aquacult. Soc. 41 (1) (2010) 35-48.

[8] F. Ozkan, S.G. Gündüz, M. Berköz, A.Ö. Hunt, S. Yalın, The protective role of ascorbic acid (vitamin C) against chlorpyrifos-induced oxidative stress in Oreochromis niloticus, Fish. Physiol. Biochem. 38 (3) (2012) 635-643.

[9] M.M. Barros, D.R. Falcon, R. de Oliveira Orsi, L.E. Pezzato, A.C. Fernandes, I.G. Guimarães, A. Fernandes, C.R. Padovani, M.M.P. Sartori, Non-specific immune parameters and physiological response of Nile tilapia fed $\beta$-glucan and vitamin C for different periods and submitted to stress and bacterial challenge, Fish. Shellfish Immunol. 39 (2) (2014) 188-195.

[10] A. Tewary, B.C. Patra, Use of vitamin $C$ as an immunostimulant. Effect on growth, nutritional quality, and immune response of Labeo rohita (Ham.), Fish Physiol. Biochem. 34 (3) (2008) 251-259.

[11] F. Garcia, F. Pilarski, E.M. Onaka, F.R. Moraes, Performance and hematology of pacu fed diets supplemented with vitamins C and/or E, Sci. Agric. 68 (3) (2011) 314-319.

[12] F.M. Campos, S.M.R. Ribeiro, C.M. Della Lucia, P.C. Stringheta, H.M. PinheiroSant'Ana, Optimization of methodology to analyze ascorbic acid and dehydroascorbic acid in vegetables, Quim. Nova 32 (2009) 87-91.

[13] J. Yunis-Aguinaga, G.S. Claudiano, P.F. Marcusso, W.G. Manrique, J.R.E. de Moraes, F.R. de Moraes, J.B. Fernandes, Uncaria tomentosa increases growth and immune activity in Oreochromis niloticus challenged with Streptococcus agalactiae, Fish. Shellfish Immunol. 47 (1) (2015) 630-638.

[14] M. Castro, G.S. Claudiano, N.L. Bortoluzzi, E. Garrido, R.Y. Fujimoto, M.A. Belo, M. Shimada, J.R. Moraes, F.R. Moraes, Chromium carbochelate dietary supplementation favored the glucocorticoid response during acute inflammation of Piaractus mesopotamicus, Aquaculture 432 (2014) 114-118.

[15] A. Sarkar, S. Mousumi, R. Pranab, Identification and typing of Aeromonas hydrophila through 16S rDNA-PCR fingerprinting, J. Aquac. Res. Dev. 2012 (2012).

[16] M. Tavares-Dias, F.R. Moraes, Características hematológicas da Tilápia rendalli Boulenger, 1896 (Osteichthyes: Cichlidae) capturada em "Pesque-Pague" de Franca, São Paulo, Brasil, Biosci. J. 19 (2003) 103-110.

[17] T.F.A. Silva, T.R. Petrillo, J. Yunis-Aguinaga, P.F. Marcusso, G. Claudiano, F.R. de Moraes, J.R.E. de Moraes, Effects of the probiotic Bacillus amyloliquefaciens on growth performance, hematology and intestinal morphometry in cage-reared Nile tilapia, Lat. Am. J. Aquat. Res. 43 (5) (2015) 963-969.

[18] F.M.M. Brito, G. Claudiano, J. Yunis, A.V. Mundim, M. Tavares-Dias, P.H. Viadanna, J.R.E. Moraes, F.R. Moraes, Hematologia, perfil bioquímico e hormônios da tireoide em quatro espécies de arraias de água doce do gênero Potamotrygon, Braz. J. Vet. Res. Anim. Sci. 52 (3) (2015) 249-256.

[19] V.R. Reque, J.R.E. Moraes, M.A.A. Belo, F.R. Moraes, Inflammation induced by inactivated Aeromonas hydrophila in Nile tilapia fed diets supplemented with Saccharomyces cerevisiae, Aquaculture 300 (2010) 37-42.

[20] M. Martins, F. Vieira, G. Jerônimo, J. Mouriño, G. Dotta, A. Speck, F. Jatoba C. Pedrott, G. Buglione-Neto, G. Pereira, Leukocyte response and phagocytic activity in Nile tilapia experimentally infected with Enterococcus sp, Fish. Physiol. Biochem. 35 (2009) 219-222, http://dx.doi.org/10.1007/s10695-0089262-X.

[21] Y.V. Rao, B.K. Das, P. Jyotyrmayee, R. Chakrabarti, Effect of Achyranthes aspera on the immunity and survival of Labeo rohita infected with Aeromonas hydrophila, Fish. Shellfish Immunol. 20 (3) (2006) 263-273.

[22] D.C. Fernandes, S.F. Eto, G.S. Claudiano, P.F. Marcusso, F.C. Vieira, M.T. Shimada, Thiago F.A. Silva, E.C. Souza, R. Salvador, J.E. Moraes, F.R. Moraes, Humoral immune response in Oreochromis niloticus: modified direct agglutination test, Comp. Clin. Pathol. 24 (3) (2015) 617-623.

[23] W.G. Manrique, G. Claudiano, T.R. Petrillo, M. Castro, M.A. Pereira Figueiredo, M. Belo, J.R.E. Moraes, F.R. Moraes, Response of splenic melanomacrophage centers of Oreochromis niloticus (Linnaeus, 1758) to inflammatory stimuli by BCG and foreign bodies, J. Appl. Ichthyol. 30 (2014), http://dx.doi.org/10.1111/ jai.12445, 1001e1006.

[24] S. Amaral, L. Mira, J. Nogueira, A. Silva, M. Florencio, Plant extracts with antiinflammatory properties: a new approach for characterization of their bioactive compounds and establishment of structure e antioxidant activity relationships, Bioorg. Med. Chem. 17 (2009) 1876-1883.

[25] P. Kloucek, Z. Polesny, B. Svobodova, E. Vlkova, L. Kokoska, Antibacterial screening of some Peruvian medicinal plants used in Callería District, J. Ethnopharmacol. 3 (99) (2005) 309-312.

[26] E. Saccol, C. Toni, T. Pês, G. Ourique, L. Gressler, L. Silva, R. Mourão, R. Oliveira, B. Baldisserotto, M. Pavanato, Anaesthetic and antioxidant effects of Myrcia sylvatica (G. Mey.) DC. and Curcuma longa L. essential oils on tambaqui (Colossoma macropomum), Aquac. Res. (2016) (in press).

[27] C. Majolo, S. Barros, E. Campos, F. Maia, H.B. Ribeiro, Chemical composition of Lippia spp. essential oil and antimicrobial activity against Aeromonas hydrophila, Aquac. Res. (2016) (in press).

[28] D. Fracassetti, C. Costa, L. Moulay, F.A. Tomás-Barberán, Ellagic acid derivatives, ellagitannins, proanthocyanidins and other phenolics, vitamin $\mathrm{C}$ and antioxidant capacity of two powder products from camu-camu fruit (Myrciaria dubia), Food Chem. 139 (1) (2013) 578-588. 
[29] R. Chen, R. Lochmann, A. Goodwin, K. Praveen, K. Dabrowski, K.J. Lee, Effects of dietary vitamins $\mathrm{C}$ and $\mathrm{E}$ on alternative complement activity, hematology, tissue composition, vitamin concentrations and response to heat stress in juvenile golden shiner (Notemigonus crysoleucas), Aquaculture 242 (1) (2004) $553-569$.

[30] Q. Zhou, L. Wang, H. Wang, F. Xie, T. Wang, Effect of dietary vitamin C on the growth performance and innate immunity of juvenile cobia (Rachycentron canadum), Fish. Shellfish Immunol. 32 (2012) 969-975.

[31] S.K. Nayak, P. Swain, S.C. Mukherjee, Effect of dietary supplementation of probiotic and vitamin $C$ on the immune response of Indian major carp, Labeo rohita (Ham.), Fish. Shellfish Immunol. 23 (2007) 892-896.

[32] E.G. Affonso, E. da Costa Silva, M. Tavares-Dias, G.C. de Menezes, C.M. de Carvalho, D.S. Nunes, D.R. Ituassúa, R. Roubacha, E.A. Onoa, J.D. Indrusiak Fi, J.L. Marcon, Effect of high levels of dietary vitamin $C$ on the blood responses of matrinxã (Brycon amazonicus), Comp. Biochem. Physiol. A Mol. Integr. Physiol. 147 (2) (2007) 383-388.

[33] G.C. de Menezes, M. Tavares-Dias, E.A. Ono, J.A. de Andrade, E.M. Brasil, R. Roubach, E.C. Urbinati, J.L. Marcon, E.G. Affonso, The influence of dietary vitamin $\mathrm{C}$ and $\mathrm{E}$ supplementation on the physiological response of pirarucu, Arapaima gigas, in net culture, Comp. Biochem. Physiol. A Mol. Integr. Physiol. 145 (2) (2006) 274-279.

[34] J.A. de Andrade, E.A. Ono, G.C. de Menezes, E.M. Brasil, R. Roubach, E.C. Urbinati, M. Tavares-Dias, J.L. Marcon, E.G. Affonso, Influence of diets supplemented with vitamins $\mathrm{C}$ and $\mathrm{E}$ on pirarucu (Arapaima gigas) blood parameters, Comp. Biochem. Physiol. A Mol. Integr. Physiol. 146 (4) (2007) $576-580$.

[35] C.K. Misra, B.K. Das, S.C. Mukherjee, J. Pradhan, Effects of dietary vitamin C on immunity, growth and survival of Indian major carp Labeo rohita, fingerlings, Aquacult Nutr. 13 (1) (2007) 35-44.

[36] J.X. Wilson, Mechanism of action of vitamin C in sepsis: ascorbate modulates redox signaling in endothelium, Biofactors 35 (1) (2009) 5-13.
[37] I.R. Tizard, Citocinas e sistema imune, in: I.R. Tizard (Ed.), Imunologia Veterinária: uma Introdução, vol. 12, 2002, pp. 140-153. São Paulo, Roca.

[38] K.G. Lourenço, G.S. Claudiano, S.F. Eto, J.Y. Aguinaga, P.F. Marcusso, R. Salvador, J.R.E. Moraes, F.R. Moraes, Hemoparasite and hematological parameters in Nile tilapia, Comp. Clin. Pathol. 23 (2) (2014) 437-441.

[39] M. Tavares-Dias, F.R. Moraes, Hematology in Teleosts Fish, 2004, p. 144. Ribeirão Preto, São Paulo.

[40] D.J. Hill, M.B. Hallett, A.F. Rowley, Effect of prostanoids and their precursors on aggregation of rainbow trout thrombocytes, Am. J. Physiol. 276 (1999) 659-664.

[41] P. Lloyd-Evans, S.E. Barrow, D.J. Hill, Eicosanoid generations and effects on the aggregation of thrombocytes from the rainbow trout, Oncorhynchus mykiss, Biochim. Biophys. Acta 1215 (1994) 291-299.

[42] J. Yunis-Aguinaga, G.S. Claudiano, P.F. Marcusso, C. Ikefuti, G.G. Ortega, S.F. Eto, C. da Cruz, J.R. Moraes, F.R. Moraes, J.B. Fernandes, Acute toxicity and determination of the active constituents of aqueous extract of Uncaria tomentosa Bark in Hyphessobrycon eques, J. Toxicol. 2014 (2014) 1-5.

[43] G. Dotta, J.I. de Andrade, E.T. Gonçalves, A. Brum, J. Mattos, M. Maraschin, M.L. Martins, Leukocyte phagocytosis and lysozyme activity in Nile tilapia fed supplemented diet with natural extracts of propolis and Aloe barbadensis, Fish. Shellifish Immunol. 39 (2) (2014) 280-284.

[44] A.M. El-Asely, A.A. Abbass, B. Austin, Honey bee pollen improves growth, immunity and protection of Nile tilapia (Oreochromis niloticus) against infection with Aeromonas hydrophila, Fish. Shellfish Immunol. 40 (2) (2014) $500-506$.

[45] C. Ngugi, E. Oyoo-Okoth, J. Mugo-Bundi, P. Sagwe, E. Jepyegon, P. Aloo, Effects of dietary administration of stinging nettle (Urtica dioica) on the growth performance, biochemical, hematological and immunological parameters in juvenile and adult Victoria Labeo (Labeo victorianus) challenged with Aeromonas hydrophila, Fish. Shellfish Immunol. 44 (2015) 533-541. 